\title{
NOTAS SOBRE UM ROLÉ DE ESCUTA ATIVA NA FEIRA DE SÃO JOAQUIM: UMA ETNOGRAFIA SONORA E FOTOGRÁFICA
}

\author{
NOTES ABOUT AN ACTIVE LISTENING ROLLER AT SÃO JOAQUIM FAIR: $A$ \\ SOUND AND PHOTOGRAPHIC ETHNOGRAPHY
}

Lucas Barreto de Souza ${ }^{1}$

RESUMO: Este artigo é resultado de uma tarefa teórico-metodológica a que me dispus e está pautado em algumas reflexões teórico-conceituais e metodológicas trançadas a trabalho de campo realizado no ano de 2016, parte integrante da monografia intitulada "Feira de São Joaquim: artigos religiosos e agência não humana" - monografia apresentada a sete de abril de 2017, na faculdade de Filosofia e Ciências Humanas da Universidade Federal da Bahia (FFCH/UFBA), sob orientação do prof. Marcelo Moura Mello e coorientação do prof. Fernando Firmo Luciano, de minha autoria, bem como em experiências de pesquisa etnográfica sonora previamente realizada, no ano de 2015, no âmbito do projeto de PIBIC "Olhares e escutas antropológicas sobre a Baía de Todos os Santos", sob orientação do prof. Fernando Firmo Luciano, entre 2014 e 2015. Almejo a esboçar uma descrição da Feira de São Joaquim e da diversidade que a caracteriza. Essa descrição é da configuração anterior às recentes mudanças ocorridas após inauguração da parte nova da feira, em 2016. No tempo, o trabalho está localizado num período provisório, de transformações estruturais em São Joaquim. Importante apontar para o uso do "presente etnográfico", conforme a definição de James Clifford, no primeiro capítulo do livro "A experiência etnográfica”, intitulado "Sobre a autoridade etnográfica". Apresentar uma pequena mostra da memória histórica da feira, a partir da experiência de um frequentador interlocutor, conforme por ele expressa. Marcar inferências e inflexões surgidas ao longo do tempo transcorrido de convivência com os feirantes. Refletir e explorar a ideia do papel do gravador como elemento adicional na trama, instrumento mediador da relação pesquisadores - interlocutores. Contribuir para o desenvolvimento teórico das reflexões em torno dos conceitos de campo sonoro e paisagem sonora, discussão que relaciona e confronta ideias apresentadas pelos autores Carlos Fortuna (1998), Murray Schaffer (1994) e Tim Ingold (2012) de modo amplo, além de abordar algumas questões referentes ao corpus da pesquisa e ao lócus específico.

Palavras-chave: etnografia sonora, antropologia visual, antropologia urbana, mercados populares, feiras.

ABSTRACT: This article is a result of a work research based in some concept theorical and methodologicals reflections added to fieldwork realized in 2017, part of the monography São Joaquim Market: religious articles and not human agency (presented in 7 april 2017, at FFCH of UFBA), oriented by prof. Marcelo Moura Mello and cooriented by prof. Fernando Firmo Luciano, as well in some sonorous ethnographic experiences previewsly realized in 2015, for the PIBIC project Olhares e escutas antropologicas sobre a baía de Todos os Santos (anthropological glances and bugging to the all saints bay - free translation), mediant orientation by prof. Fernando Firmo

\footnotetext{
${ }^{1}$ Discente do curso do mestrado em antropologia pelo Programa de Pós-graduação da Universidade Federal da Bahia (PPGA/UFBA).
} 
Luciano, between 2014 and 2015. Search to design a description of São Joaquim market and of the diversity that caracterized it. This description is about the preview configuration, before the recent changes/ transformations ocurred at the new building at that market, 2016. On time, the work is localized in a provisory period, of strucutral transformations in S. Joaquim market. Is very important to sinalize the use of the "etnographic present", acordding the J. Clifford definition, in the first caphter of the book "Ethnographic experience", "On etnographic autority". To show a little of the market historical memory, according an interlocutor explains. To mark inferences and inflections arisen over time of the coexistence with the faigrounds. To reflect and explore the idea of the recorder's function like adictional element in the plot, mediator of researchers and interlocutors relations. To contribute for the theorical development about sonorous field and sound landscape, discussion that to relate and friction (confront) of ideias presented by the authors Carlos Fortuna (1998), Murray Schaffer (1994) and Tim Ingold (2012), beyond to approach some questions referents to the research corpus and the specifical locus. Keywords: sound ethnography, visual anthropology, urban anthropology, popular markets.

Key words: sound ethnography, visual anthropology, urban anthropology, popular markets.

\section{APRESENTAÇÃO}

A feira de São Joaquim está situada em Salvador, na cidade baixa, mais especificamente na av. Eng. Oscar Pontes, entre a estação da barca férrea e um cais, na enseada de São Joaquim. Possui extensão territorial de aproximadamente 35 mil metros quadrados. Estima-se que, em média, 20 a 30 mil pessoas frequentem diariamente a feira, atendidos e servidos por 5 mil feirantes "fixos", mais 2 mil "circulantes", totalizando 7 mil trabalhadores, universo do qual 20\% são mulheres, $80 \%$ são homens; $80 \%$ são negros e $75 \%$ tem mais de 50 anos de idade. Maioria de pretos e pardos, do sexo masculino e um alto percentual de idosos (dados do SINDIFEIRA - sindicato dos feirantes). Figura entre os mais importantes mercados do país, com extensão territorial comparável à do mercado Ver-o-peso, em Belém do Pará, ou à feira de Caruaru, em Pernambuco. Embora não funcione à noite como o Ver-o-peso, em Belém, ou tenha estilo arquitetônico neoclássico europeu como mercado São José, em Recife, tem marca própria, exuberância, conflitos, contrastes e vida pulsante. Uma feira essencialmente de rua. 

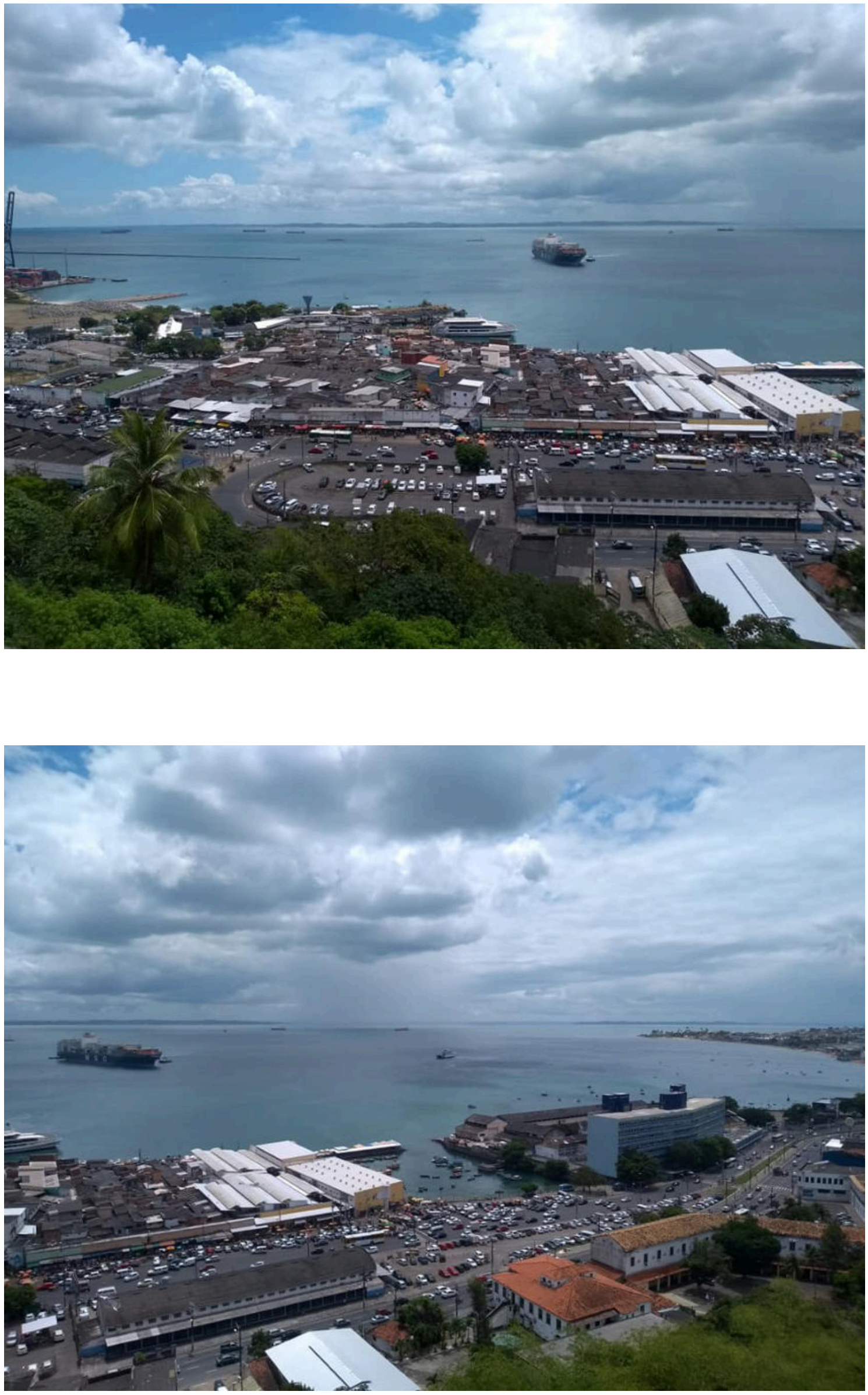
Foi cenário de reportagens, filmes ficcionais e documentais. Registrada por fotógrafos conceituados, amadores e iniciantes. Reverenciada em apresentações musicais no próprio local e presenteada com intervenções artísticas em seus muros antigos e novos. É possível notar expressões artísticas nos muros dos estreitos corredores da feira de São Joaquim. Pinturas, grafites feitos com sprays, expressando imagens de personagens fantásticas, animais, abstracionismos, figuras multicoloridas. A arte está em toda a feira, porém nenhum outro lugar, num período específico, parece ter concentrado tantas pinturas quanto os muros do galpão utilizado provisoriamente para alocar os feirantes que aguardavam a construção de uma nova estrutura para a feira. Na área do Galpão Água de Meninos (demolido em meados de 2018), após a sua desocupação quando do processo de transferência de feirantes e mercadorias para um novo espaço erguido junto ao cais, toda a área sofreu forte intervenção artística, em paredes internas e externas, muros laterais e do fundo, até que o espaço foi totalmente alterado, com divisões internas demolidas, muros de fundo pintados, e a área passou a ser utilizada como estacionamento para táxis que servem aos usuários do sistema ferry-boat. Há uma estação das barcas férreas vizinha à feira, ligando, por mar, a capital Salvador aos municípios de Vera Cruz e Itaparica, do outro lado da baía de Todos os Santos.

O tradicional samba acontece na área externa, no cais, numa área específica, parcialmente coberta, geralmente aos domingos, com vista para a baía: ao fundo, barcos aportados, à frente, o mar da baía de Todos os Santos; ao lado, a feira de São Joaquim e a estação da barca férrea. $\mathrm{Na}$ inauguração da Nova Feira de São Joaquim, houve uma grande festividade, com apresentação de grupos e artistas nacionais reconhecidos. Outro acontecimento emblemático é a festa do marujo, cuja matrona é Dona Dadá, feirante do ramo de serviços de alimentação, que tem um restaurante/ bar na feira de São Joaquim. Um cortejo percorre todo o espaço da feira, com instrumentos musicais, estandartes, reverências e a animação típica das marujadas. A celebração ocorre anualmente e foi registrada pelo grupo CINES/UFBA (Coletivo de Imagem, Etnografia e Sonoridades), coordenado pelo prof. Fernando Firmo, antropólogo cineasta, em 2014. No galpão demolido, podia ser regularmente verificada a ocorrência de apresentações musicais num pequeno espaço elevado, palco e também passagem, de grupos locais e de viajantes internacionais, especialmente sul-americanos, peruanos/as e bolivianos/as, colombianos/as, músicos com flautas andinas e tambores marcantes, especialmente aos sábados, por volta do horário comercial de almoço.

Grupos de praticantes de fotografia, turmas de iniciantes, frequentemente são vistas pela feira, em busca de fazer observações no mundo fora dos estúdios, não de representações, de 
um diversificada gama de texturas, cores, formas, modos de arrumação, de interatividade, multiplicidade comportamental social, expressões e gestos faciais - corporais, agitação, movimento, vida (INGOLD, 2012). Passagens pelo local de fotógrafos/as mais experientes - o fotógrafo Pierre Verger, por exemplo - publicados em livros, revistas, meios digitais e arquivos, podem ser constatadas. Registros fílmicos foram realizados para cinema, "A Grande Feira” (1961), dirigido por Roberto Pires, “Sol sobre a lama (1963), de Alex Viany, e “Água de Meninos - a feira do cinema novo" (2012), documentário, Fabíola Aquino, que contou com exibição no galpão Água de Meninos para o público do local; videoclipes de grupos musicais e de dança com circulação pela internet, diversas matérias jornalísticas veiculadas em televisão e internet. Alguns artistas plásticos também retrataram a feira, caso de Carybé, Di Cavalcanti, Diógenes Rebouças Filho, dentre outros.

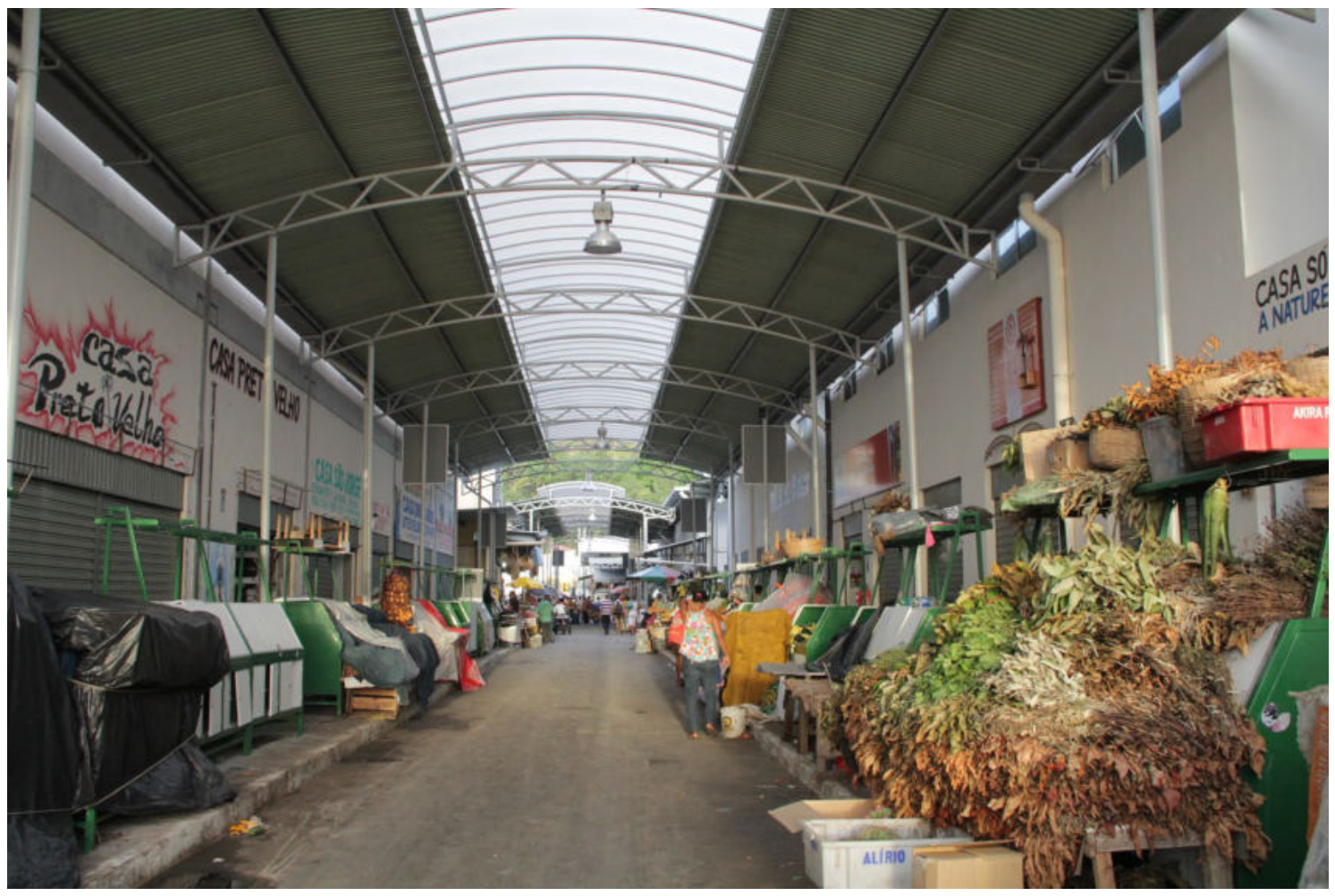




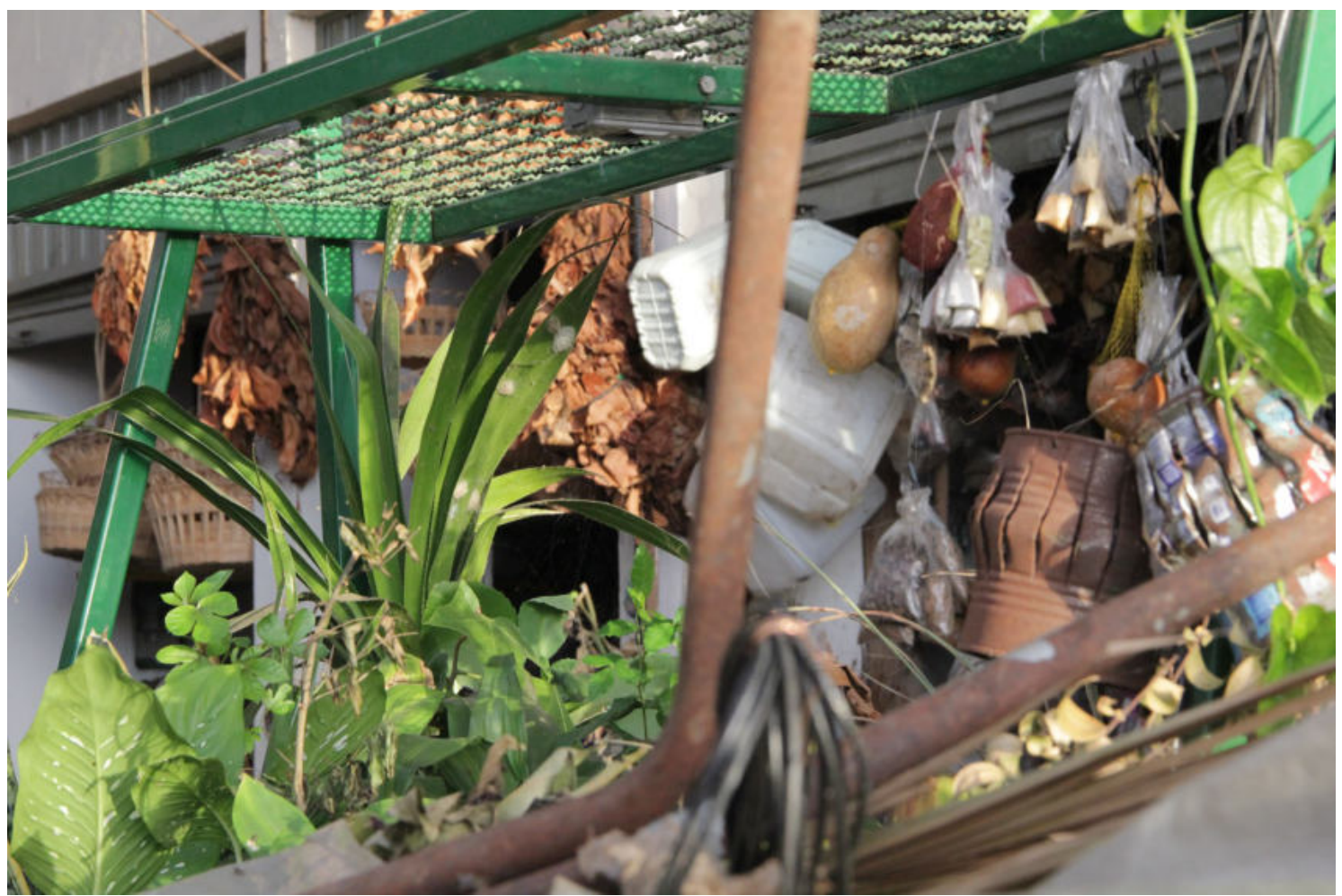

HISTÓRICO DA FEIRA (arquivo e entrevistas compiladas)

Apresentar uma pequena mostra da memória histórica da feira, a partir da experiência de um frequentador interlocutor, conforme por ele expressada; a partir de outros frequentadores e frequentadoras e de alguns feirantes consultados sobre o assunto; e a partir de trabalho de pesquisa historiográfica realizada em arquivo.

Na capital baiana, as primeiras feiras datam do século XVI. Cidade portuária, Salvador era o grande entreposto comercial, meio de escoamento de toda a produção do recôncavo baiano; seu porto era o mais movimentado das Américas. Além de produtos manufaturados e gêneros alimentícios, era mercado importador e exportador de pessoas escravizadas e ouro. Depois de período de decadência econômica (sobre o qual não convém tratar aqui a respeito pelo fato de a história não ser a questão central), a partir da descoberta de petróleo, Salvador retomava seu vigor no começo dos anos 50 do século XX, tempos depois de ter sido centro econômico do império português na América. E a feira de Água de Meninos, antecessora à feira de São Joaquim e cuja transferência provocou seu inchaço, acolhia centenas de nordestinos, retirantes, que chegavam fugidos do "polígono das secas" à procura de oportunidades na capital Salvador, o que contribuiu para o grau de importância regional, nacional, continental e mundial da feira. 
Dentre as várias versões existentes que buscam explicar a origem do nome Água de Meninos, a de Álvaro do Amaral afirma que tal nome é oriundo da nascente de água copiosa, que corria quase até o mar, formando um lago, onde os meninos se banhavam (PAIM, 2005). O Sr. Carlos, que será citado adiante, refere-se, em seu depoimento, a uma certa fonte na qual pegava água com pote ou moringa; subentende-se que não estava sozinho: "a gente pegava água fonte (...)". Ainda segundo Paim (2005), Odorico Tavares retratou o cotidiano da feira e destacou a principal rota dos produtos, o recôncavo fornecedor dos principais gêneros alimentícios que supriam à época a cidade. A autora nota ainda, por meio de pesquisa historiográfica, diversas naturalidades dos trabalhadores, diversidade de origem das mercadorias naquele espaço, citando Jannot Silveira, segundo o qual chegavam sergipanos, com arrôjos, alagoanos, paraibanos com peixeiras afiadas, abóboras trazidas do sertão, leguminosas de Itabaiana. De Jeremoabo batatas, peixe salgado do rio São Francisco, cerâmica de Maragojipe.

Ao longo do tempo, a feira foi alvo permanente do Poder Legislativo Municipal, no sentido do ordenamento, normatização, regulação e tentativas de disciplinar as feiras-livres e a localização do comércio ambulante, através da fiscalização municipal, bem como na manutenção/regulação dos preços. As autoridades consideravam incovenientes a circulação de vendedoras e vendedores ambulantes, assim como a existência de feiras permanentes: as primeiras por "atrapalhar" transeuntes, obstruindo passagens com suas "práticas abusivas nas principais artérias da capital”; as outras, sob acusação de maus hábitos de higiene, sem contudo deixar de mencionar o incômodo com a "isenção" de impostos, algo desinteressante do ponto de vista do governo municipal - "abusos" que comprometiam os foros de cidade civilizada.

Houve uma campanha pela modernização visual da cidade, justamente num momento em que se faziam sentir os efeitos da Segunda Guerra Mundial, a fim de "melhorar" o aspecto visual e barrar "comportamentos abusivos". Prefeito entre os anos 1947 e 1951, Wanderley de Araújo Pinho sancionou lei para criação de feiras livres distritais da zona urbana que visavam ainda ordenar e disciplinar as feiras de Salvador, especificamente as feiras permanentes, oferecendo prazos para que deixassem de ser permanentes, e estabelecendo horários rígidos de funcionamento. Planos foram traçados, porém desentendimentos e conflitos de interesse impediram suas execuções. É suposta a existência de possíveis conflitos entre prepostos municipais e os feirantes. A tendência de equiparação de Salvador aos modelos de higienização e civilização praticados no sudeste do país endossava interesses modernizadores desenvolvimentistas motivadores de certas ações municipais. Entretanto, a feira de Água de Meninos cresceu de forma espontânea revelando uma dinâmica bastante peculiar, de cenário sociocultural múltiplo e diversificado. 
Fontes diferentes, entre dissertações, livros, guias e jornais, atribuem dimensões diferentes à feira, entre 34 mil e 60 mil metros quadrados. O Instituto do Patrimônio Histórico Artistico Nacional (IPHAN) protocolou em 2007 um pedido de análise para reconhecimento da feira de São Joaquim como patrimônio material e imaterial do Brasil. No mesmo ano, o Ministerio da Cultura (MINC) realizou oficina para intervenções como preservação e valorização cultural, segundo dados do jornal $A$ Tarde, de 15 de agosto de 2009. Estimava-se, a este período, uma média de público diária de 20 a 30 mil pessoas e um contingente de 7,5 mil trabalhadores.

A estrutura erguida mais recentemente está em funcionamento. Os feirantes comerciantes de artigos religiosos cujas barracas estavam funcionando no galpão cedido pela Companhia das Docas do Estado da Bahia (CODEBA) foram relocados nesse outro espaço. Há também boxes ocupados por feirantes que não estavam no galpão e bancas, na calçada, em frente às lojas. Na parte mais antiga da feira, entre essas duas estruturas, há uma rua bastante conhecida e frequentada que concentra barracas de artigos religiosos.

Na década de 1960, ocorreu um incêndio na feira de Água de Meninos, antecessora à feira de São Joaquim, após o qual surgiu esta última, sua herdeira e continuação, bem como a relocação e reconfiguração por que passou. No período, houve uma transferência dos feirantes de Água de Meninos para São Joaquim e, assim, uma superposição de aspectos os mais diversos, materiais, imateriais, palpáveis ou não, físicos, simbólicos. Essa transferência se deu um ano depois. Em 1964, foram dois incêndios, o primeiro dos quais, ao dia 5 de setembro, ocasionado pela exalação de gases provenientes dos tanques de combustíveis das empresas Esso e Shell, localizados à av. Eng. Frederico Oscar Pontes, o que teria gerado combustão; o segundo incêndio, quatro dias após, destruiu a maior parte das barracas que restaram do primeiro incêndio e a responsabilidade foi atribuída a um feirante endividado que teria ateado fogo à sua própria barraca, mas nada foi provado e nada se soube sobre o seu paradeiro. Os feirantes foram relocados no ano seguinte, as indenizações saíram vinte anos depois. Outros incêndios de proporções menores ocorreram na feira nos anos 1987 e 1994. Antes da feira de Água de Meninos, era a feira dos sete, no entorno da, assim chamada, praia do sete, na região do porto de Salvador, próximo ao armazém de número sete da codeba. E havia ali ocorrido um primeiro incêndio, em abril de 1934.

À urbanização da cidade baixa e ampliação do porto de Salvador, atribuiu-se a transferência da feira do sete e o surgimento da feira de Água de Meninos. Há que se ressaltar que no período posterior ao incêndio posterior, ocorrido no ano de 1964, se deu a implementação de certa lógica organizacional do espaço por planejadores urbanos, divisão por quadras, becos, ruas (do coco, da farinha, das cerâmicas, do largo, do quiabo), qual seja racionalização do espaço, 
setorização; e, principalmente, os processos de apropriação e reinvenção pelos agentes na/da feira: a multiplicação do espaço; quadras, ruas e becos renomeados, por categorias, por feirantes e fregueses.

$\mathrm{Na}$ tentativa de conhecer uma versão nativa para a história da feira, toquei no assunto com alguns feirantes e tentei reunir as informações numa narrativa única. O resultado se aproxima das versões "oficiais" e as reforça, em alguns pontos, enquanto se distancia, em outros. Tento reconstituir esse texto como uma versão nativa, com base na memória de feirantes e frequentadores, para a história da feira. Segue a história segundo eles.

Na década de 30, era a Feira do Sete, instalada bem próxima ao galpão 7 da CODEBA, na Cidade Baixa. Havia uma aglomeração de feirantes vindos de diversas cidades do recôncavo baiano, como Santo Antônio de Jesus, Valença, Lage, Mutuípe, Salinas da Margarida, em especial as mariqeuiras nesse caso. Era o tempo dos saveiros, barcos à vela. O inchaço da feira naquela localização produziu problemas para o trânsito e a mobilidade, o que provocou a mudança de área dali para a região de Água de Meninos. O nome veio da fonte do minadouro, em que meninos se banhavam e pegavam água. Havia dificuldades à época pelo fato de a água não ser canalizada.

Entretanto, em Água de Meninos, havia a Shell do Brasil, e seu depósito, como concorrente pelo espaço. A feira crescia descontroladamente. Em 1964, ocorreu o que os mais velhos chamam de "um dos golpes na Bahia", um incêndio de grandes proporções que trouxe muitos prejuízos. Em função da dificuldade de acesso a bancos, feirantes guardavam dinheiro em caixotes e colchões, dentro dos estabelecimentos. Relatos dão conta de que havia combustível saindo dos bueiros, dos esgotos. Isso os leva a garantir que o incêndio criminoso foi provocado por interesses financeiros e políticos. Naquela época, a feira abastecia inclusive armazéns de bairro, cujos donos em grande escala eram portugueses e espanhóis. Deu-se então um novo remanejamento, desta vez para a enseada de São Joaquim. Foi feita uma parceria com o Colégio Órfão de São Joaquim, entre doações e a assinatura de um termo de acordo com qual estaria assegurada a permanência da feira naquela localidade por 50 anos. Período este esgotado atualmente.

\section{INCURSÕES EM CAMPO}

Para a realização da pesquisa, foram utilizadas ferramentas conhecidas na antropologia visual, ligadas à parte de som especialmente, equipamentos de captação de áudio, gravador portátil, 
microfone direcional, vara de boom. Em termos metodológicos, destacarei a técnica do "passeio de escuta", adotada na pesquisa:

O "passeio de escuta" inclui andar por um determinado local, por uma paisagem, por uma rua, ou por um edifício, e ao mesmo tempo prestar atenção àqueles ruídos que a atividade normal iria relegar como um segundo plano irrelevante. Essa técnica reativa a escuta e aumenta a consciência, é empregada para preparar informantes para investigações de cenários sonoros, e se poder falar sobre ambiente sonoro, tópicos que são normalmente ignorados e difíceis de verbalizar (Winkler apud Bauer e Gaskell, 2000, p. 375).

Desse modo, gravações foram realizadas, algumas com falas diretas, a maior parte não; evidenciando sonoridades sociais, possibilitando uma análise daquele contexto a partir dessas sonoridades, a feira e suas paisagens sonoras. Em seguida, realizo uma descrição da feira, reflito sobre o papel do gravador, busco aprofundar no debate teórico conceitual sobre campo sonoro e paisagem sonora, e reflito sobre a relação interlocutor - equipamento - pesquisador.

Persistindo no espaço, em meio à proliferação de shoppings centers e supermercados, na cidade de Salvador, Bahia, está a feira de São Joaquim.

Não há aqui pretensões de situar cronologicamente eventos ocorridos outrora, entretanto um breve e empolgado relato ${ }^{2}$ de um antigo frequentador da feira, Sr. Carlos, pode nos apresentar um pouco do passado/ presente do lugar, através de uma fala que reflete uma espécie de fusão (mesmo que parcial) entre a vida da feira e daquele que fala, marcante nas lembranças dos 54 anos de vida dele (em 2015).

\footnotetext{
"A maior feira do Norte/Nordeste é a feira de São Joaquim, conhecida como a feira de Água de Meninos, feira que tem de tudo e dá de tudo, aqui não falta nada. Aqui, o que você quiser (...) encontra: do coentro à hortelã à folha de louro ao sal à carne de boi à carne salgada, fora frutas e legumes e hortaliças, tudo é na feira de São Joaquim”.
}

E continuou, falando sobre a importância do recôncavo baiano produtor e dos saveiros por meio dos quais as mercadorias eram trazidas: “(Aqui) aonde os saveiros vinham de Maragojipe, de Santo Antônio de Jesus, de Nazaré das Farinhas, com farinha, muita louça de barro. Como vinha da feira fogareiro, moringa, pote/torrão. E naquele tempo não tinha água encanada mesmo.”.

E sobre a fonte e o atracadouro,

\footnotetext{
"A gente pegava água na fonte, em pote, as moringas que vinhas de Santo Antônio de Jesus, da feira de caxixi, os saveiros atracavas aqui na rampa de água de meninos. A gente comprava o pote aqui para levar para nossa casa para tomar água da fonte (...) nagé, panela de barro, moringa, pote/torrão." (Entrevista com frequentador da feira, janeiro de 2015).
}

\footnotetext{
2 “Entrevista espontânea” ou conversa informal gravada, com autorização do depoente, em janeiro de 2015.
} 
Na primeira das visitas (a nova estrutura não estava em funcionamento, janeiro de 2015), a entrada no espaço da feira se deu por um grande portão (portão que atualmente em geral se encontra fechado), localizado ao lado da entrada do ferry-boat, área que abrigava um galpão da CODEBA (Companhia das docas do Estado da Bahia), cedido provisoriamente e atualmente desmanchado. A partir daqui, narro como se fosse agora o evento.

Ali soam samba de roda, samba chula, cantos e toques de capoeira e candomblé; um senhor, com seu chapéu de couro, seu carrinho com sistema de som, Seu Neco, apresenta-nos parte dos produtos que comercializa: qualidades, tipos, lugar de onde procedem as manifestações culturais, artísticas e religiosas veiculadas nos CDs.

Inicialmente, a ideia era concentrar a observação no galpão Água de Meninos, espaço cedido pela CODEBA (Companhia das Docas do Estado da Bahia) para abrigar temporariamente lojas, boxes, barracas e bares, em função da construção da nova estrutura, erguida junto ao cais de São Joaquim, para onde foram relocados. "Visite o galpão - artigos religiosos, produtos baianos, ovos, cereais e farinha, carnes salgadas e defumadas, confecções e mais", chamada escrita numa placa em frente ao galpão. 


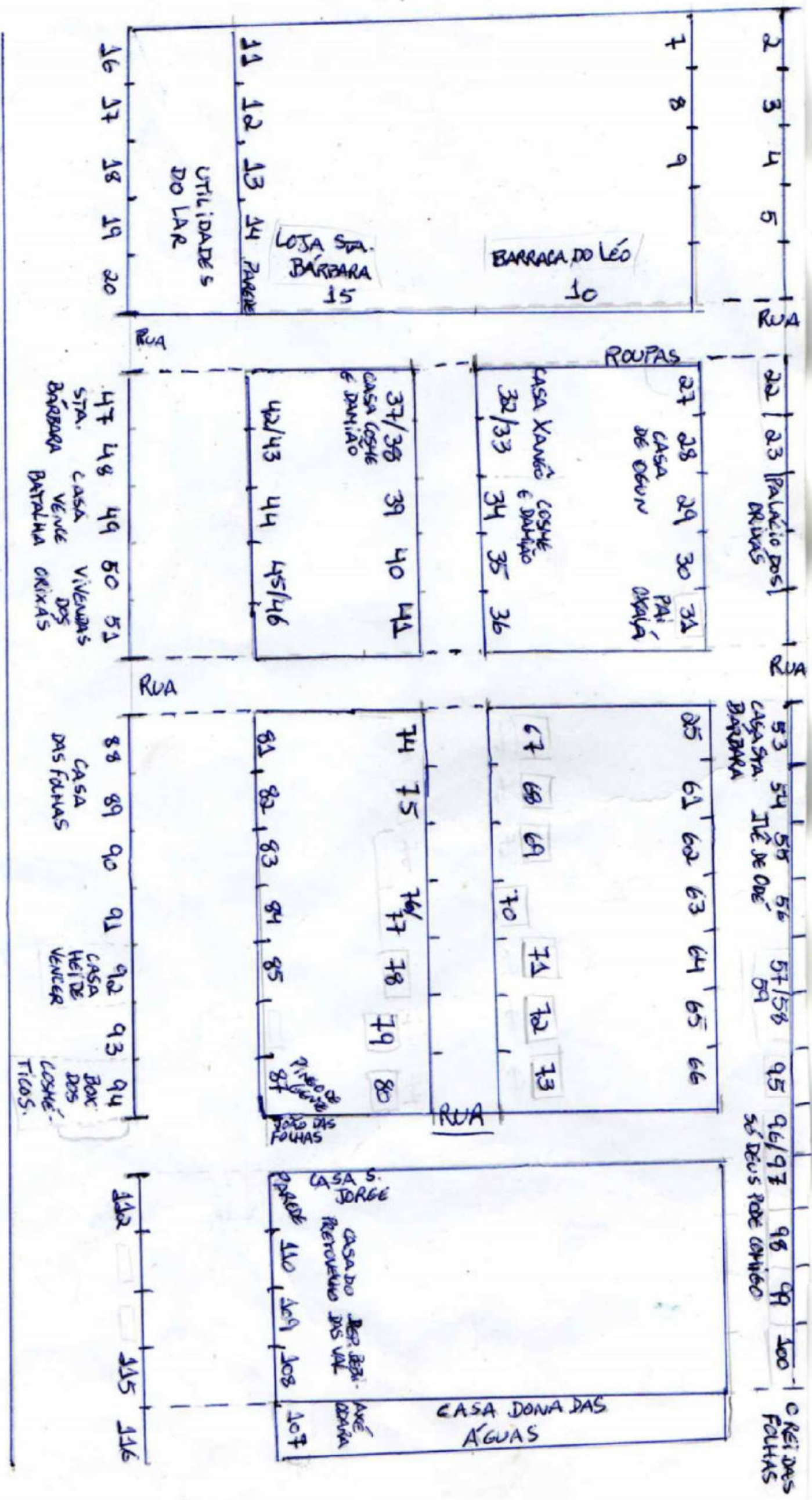


Apesar disso, carnes salgadas não se encontrava lá e, além dos produtos descritos na placa, havia utensílios do lar e alguns bares/ restaurantes. No galpão, contabilizei dezoito barracas de artigos religiosos, e duas bancas de folhas, na parte interna; na parte externa, duas barracas.

Encontrei termos diferentes - barraca, casa, loja, ilê, palácio - escritos nas placas colocadas nas paredes, na parte superior aos boxes. O fato é que essa nomenclatura varia de acordo com o arbítrio de cada proprietário, o que amplia a gama de nomes dados aos espaços, porém existe uma classificação básica, segundo a medição efetuada pela CONDER (Companhia de Desenvolvimento Urbano do Estado da Bahia): palete, banca e box. Uma divisão simplificada entre blocos e bancas também é convencional. O galpão Água de Meninos, espaço de uso provisório pelos feirantes, comportou boxes destinados à comercialização de utensílios domésticos, ou “utilidades do lar", e variedades, do lado mais próximo à entrada do ferry-boat; bares e restaurantes, numa parte elevada, do lado oposto, fazendo fronteira com a peixaria; e, entre esses dois extremos, os boxes voltados para os artigos religiosos propriamente, no "miolo" do galpão. A estrutura interna: dois corredores principais e passagens transversais, sendo três fileiras principais de boxes, descontínuas, por conta das passagens transversais. Na parte externa do galpão, junto ao muro, havia algumas barracas, dentre as quais duas voltadas à comercialização de artigos religiosos diversificados, outras à de animais vivos, outras ainda à de flores. O galpão foi desativado ${ }^{3}$.

Em seguida, à frente, vendedoras de caranguejo, camarão fresco, mariscos, chamam clientes e negociam suas mercadorias. Rumando para a esquerda, soa o som dos carrinhos (aliás, por toda parte), o rolamento das rodas; carregadores ("carrinhos") conversam entre si, com feirantes e passantes: saudações, cumprimentos, chamadas de atenção, pedidos de licença, uma chamada de um vendedor ambulante publicizando seu produto, que pode ser, por exemplo, um preparado à base de ervas recomendado para curar diversos problemas de saúde ou atenuar sintomas.

Ao lado esquerdo daquela entrada, após algumas bancas de hortaliças, a sede da organização estrutural, órgão que dá suporte em questões relacionadas à limpeza e organização do espaço, atuante após o início das mudanças ocasionadas pela reforma da feira. Ao lado direito, o espaço do estacionamento dos caminhões - setor destinado a carga e descarga (não é o único, ao fundo da feira há outra área destinada à mesma finalidade) e a sede do SINDIFEIRA (Sindicato dos Feirantes), uma construção de andar em cujo térreo funcionam um banheiro, de um lado, e uma borracharia, de outro, já em frente a outra entrada para a feira.

\footnotetext{
${ }^{3}$ Esse é um fato bastante significativo. Era dia 18 de agosto de 2015, cheguei ao micro local (naquele momento) recortado para a pesquisa e o encontrei completamente desconfigurado.
} 
Mais adiante, os animais e seus sons. Cabras, galinhas, pássaros, dentre outros animais, emitindo sons, de dentro e de fora das jaulas/gaiolas que ficam numa parte específica, após uma pequena área destinada a bares/ restaurantes na parte provisória da feira, fora do galpão. Galpão, ponto pelo qual se pode passar na sequência; onde se vende, dentre outros artigos, registros audiovisuais relacionados ao candomblé, registros de festas de orixás, encantados, documentários diversos. D. Veca também trabalha ali, vende incensórios, em seu Box, onde funciona uma distribuidora de bebidas, junto a diversos outros trabalhadores que comercializam uma imensa variedade de artigos religiosos: tronos, imagens, contas, talismãs, folhas, ervas curativas, iguarias, especiarias diversas; mas também roupas, ovos, variedades, utensílios domésticos. Além dos serviços, bares e restaurantes por toda a feira, dentro e fora do galpão Água de Meninos e espalhados por alguns corredores da parte mais antiga. Há oferta de flores (e arranjos delas), mel, dendê. Ao lado deste galpão, existe outro, o dos peixes, a peixaria (em processo de desmanche atualmente).

À direita da referida entrada, frutas e verduras diversas, num labirinto repleto de temperos, cores, raízes, sons e aromas; pessoas interagindo, pesquisando preços, a qualidade dos produtos, conversando sobre assuntos pessoais, reencontrando conhecidos, entre os feixes de luz que invadem os corredores, descortinando cenas. No setor das carnes, a sonoridade varia, soam processadores e o riscar de facas sendo amoladas. Próximo a este setor há outro, onde é possível encontrar variedades e utensílios domésticos.

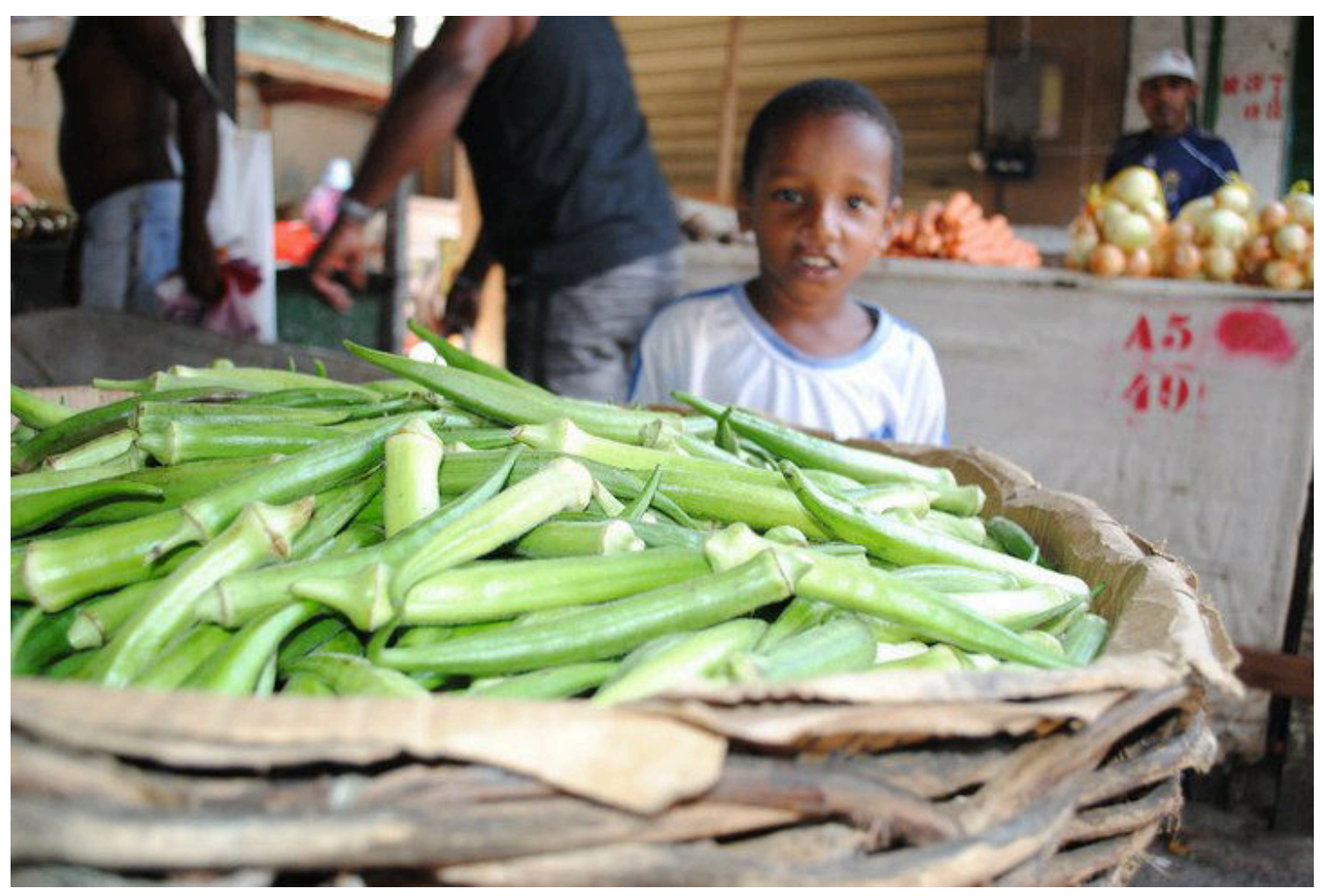


Durante o trabalho de campo, naquela etapa, em 2015, saltou-nos aos olhos o problema da alteridade, convidando-nos a pensar acerca da relação com o outro, que está a ser construída naquele momento. Um interessante comentário pareceu apontar, de modo conciso e preciso, nosso objetivo ali. Edil, feirante e sambista, muito sagaz, logo revelou algo sobre o seu entendimento acerca do que considerava se tratar a pesquisa, chegando a ser irônico em certo ponto: "eles querem saber como é o comportamento do feirante. Olha lá como o feirante fala, olha como ele se comporta". Um "deles" falando sobre o que "nós" queríamos ali saber sobre "eles", o que aponta para um interesse dos interlocutores por saber qual a intenção ou finalidade da pesquisa sobre o seu cotidiano. E, conjeturando sobre a relação com o gravador, estimula um colega a participar: “vá lá, fale, mas fale bonito, porque está gravando...".

\section{O GRAVADOR MEDIADOR}

A relação com o interlocutor passa a ser mediada por um instrumento ou ferramenta, elemento adicional na trama: o gravador. Embora não esteja sempre ligado, interfere na situação, influencia, chama para si a atenção dos envolvidos, ainda que momentaneamente. As relações agora envolvem pesquisador, gravador e interlocutor. Alguns feirantes riram ao ver passar o pesquisador com gravador, fone, microfone, num estranhamento que rapidamente conduz a uma associação com algum meio de mídia. "É o que isso aí?”, ao que outro responde: “Aí é tipo um HD”. "É da televisão aí, é?”, outro questiona. “O que é isso que vocês estão fazendo aí?”. Do modo como me veio à mente naquele momento: um trabalho de pesquisa, em antropologia, por meio da captação e análise de sonoridades sociais, uma etnografia sonora.

O comentário de uma feirante, vendedora de frutas, ajudada por seu filho: "Pra filmar agora vai ter que pagar", seguido de um sorriso, que indicava ser uma "brincadeira", algo que soou mais como um pedido de satisfação, de explicação sobre o que se passava, por que motivo aquele gravador estava junto a eles. E a chamada de atenção para a necessidade de comunicar antes de gravar, explicar do que se trata, posto que captar áudio ou imagem, sem aviso prévio e/ou liberação, pode gerar desconforto, ser considerado abusivo e invasivo.

Em ambientes públicos, é permitida a gravação de imagens e sons, mesmo que no quadro apareçam pessoas em segundo plano e suas vozes possam ser escutadas. Entretanto, o que entra em questão muitas vezes é o uso das imagens e, desse modo, os direitos de imagem. Nesses casos sim, faz-se necessária a liberação dos direitos de uso de imagem para fins específicos. Já neste caso específico, independentemente do fato de ser permitido capturar imagens em âmbito público, entra 
em jogo uma outra questão, esta mais ligada ao fomento a uma relação empática com os interlocutores, de modo a evitar animosidades.

\section{PAISAGEM SONORA E CAMPO SONORO}

Os dados coletados no primeiro momento de trabalho de campo na feira foram condensados nesta parte. Uma das visitas, em especial, conduz o "esqueleto" da narrativa, a mais "frutífera" dentre as realizadas com um gravador portátil de áudio. Por considerar esta uma observação em movimento, que envolve escuta, observação e imersão, torna-se importante trazer uma conceituação conhecida na área da etnografia sonora. Com relação à escuta/ recepção das sonoridades, ao ponto de escuta no qual o pesquisador se posiciona para acessar, e ser alcançado, pelos sons do/no lugar, é importante marcar a diferenciação entre campo sonoro e paisagem sonora. O primeiro é um "espaço acústico gerado a partir de uma determinada fonte emissora que irradia e faz distender a sua sonoridade a uma área ou território bem definidos" (FORTUNA, 1998), e o centro deste campo é certo agente emissor, humano ou não, cuja origem tende a ser ocultada pela mistura com outros sons quando da sua propagação; fazem destacar a ação de produção/emissão de sonoridades. Campos sonoros se sobrepõem vários, articulando-se entre si. O que está em destaque quando se pensa no conceito de campo sonoro é a fonte que emite sonoridade, agente humano ou não do qual é originado o som propagado no espaço.

Paisagem sonora, por sua vez, refere-se ao ato de apropriação/recepção do som e parece capaz de reterritorializar e tornar específica a acústica indiferenciada do campo sonoro; composta por um ambiente sonoro multifacetado que envolve os diferentes sujeitos-receptores. A paisagem sonora é antropocêntrica, uma vez que o sujeito humano, na qualidade de receptor, constitui o seu centro (FORTUNA, 1998). Basicamente, o que diferencia os dois conceitos é o referencial, que no caso de paisagem sonora é sempre um sujeito humano, enquanto em se tratando de campo sonoro o referencial é o agente emissor, que pode ser humano ou não.

Para Tim Ingold (2014), o conceito de paisagem sonora, introduzido em 1994 pelo compositor Murray Schafer, serviu a um propósito retórico ao apontar para um registro sensorial negligenciado em relação à visão. Por outro lado, segundo o autor, uma importante característica do conceito (prototípico) de paisagem é a não vinculação a um registro sensorial específico.

O sentido da visão nos permite ver algo à luz, ou melhor, na luz; imersos na luz, de modo que as coisas se tornam visíveis:

Luz - visão (ver) - visível. 
Visual, por sua vez, é, por exemplo, uma paisagem apresentada por alguma (mediação) técnica que promova dissociação dos sentidos, purificação artificial, permitindo que possa ser vista indiretamente. A paisagem não está lá, porém é indiretamente apresentada.

Desse modo, o mesmo valeria para o som:

\section{Som - audição (ouvir) - audível.}

Auditivo portanto refere-se a uma sonoridade apresentada por mediação técnica, de modo a dissociar os sentidos, purificação artificial, a apresentar indiretamente um som ou sons, uma paisagem sonora.

A respeito da materialidade do som, Ingold considera que, nem mental, nem material, o som é fenômeno da experiência, da imersão. E, quanto à dicotomia subjetividade/objetividade, reflete quanto ao modo como são colocadas questões que a envolvem, notando um equívoco a que a rígida divisão mundo da mente $x$ mundo da matéria conduziu. Temos, então, o som e a luz, entendidos como partes de um meio em cujos fluxos podemos perceber objetos. O som não é objeto, mas o meio de nossa percepção; não é o que ouvimos, mas aquilo em que ouvimos. E "a escuta atenta, em oposição à audição passiva, certamente implica o oposto do posicionamento"; o ambiente é o meio do conhecimento (STEIL, 2014), o confinamento é surdez (INGOLD, 2012).

\section{CARREGADORES, PRANCHAS E CARRINHOS}

Por toda parte, soa o som dos carrinhos. Os carrinhos (carregadores) respondem pela circulação de bens e mercadorias de dentro para fora da feira (e vice-versa) e dentro dela. $\mathrm{O}$ rolamento das rodas produz uma sonoridade marcante. Quase tudo que circula ali parece depender deste meio de transportar mercadorias e compras; apesar de motos também circularem pelas ruas estreitas e corredores, não são tão numerosas quanto os carrinhos, nem levam o mesmo volume de coisas. É possível que a utilização desses carrinhos tenha a ver com a dimensão da feira - algo que a diferencia de grande parte das outras feiras da cidade de Salvador. Há uma borracharia, voltada para suporte na manutenção desses equipamentos, que está localizada na mesma construção que abriga a sede do sindicato dos feirantes - SINDIFEIRA. 


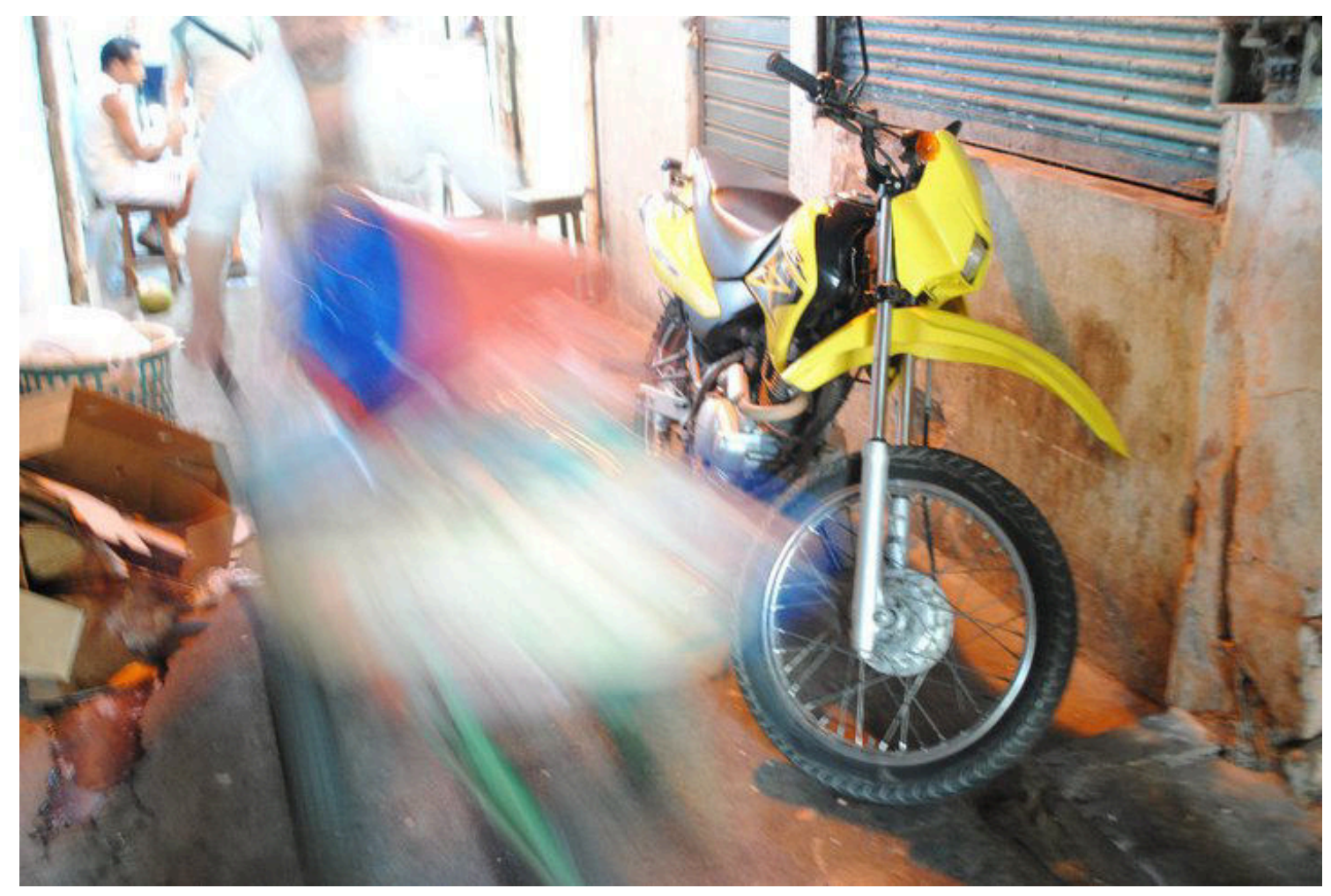

"Carrinho" é o nome dado tanto ao acessório, o próprio carrinho, quanto ao trabalhador que o conduz, também chamado de carregador. Os carregadores são trabalhadores organizados, alguns usam coletes numerados, outros não; alguns possuem carrinho-de-mão ou prancha própria, outros não, nesse caso, alugam de um armazém/ garagem de carrinhos-de-mão, na própria feira. Todos são autônomos. Pode ser notada uma separação entre os carrinhos que atuam de modo "formal", os formalizados, e os que trabalham "informalmente". Os custos para contratar o serviço de transporte de mercadorias oscila geralmente entre cinco (para carrinhos) e dez reais (para pranchas), até um estacionamento ou parada de ônibus próxima.

Da relação entre os “carrinhos" e a organização sindical dos feirantes, existe apoio do sindicato à atuação de agências que cadastram, seguindo certos requisitos, egressos de presídios. Parte dos "carrinhos" são portanto ex-detentos, que cumpriram pena anteriormente, em atividade laboral na feira; reinseridos no mundo do trabalho, via mediação promovida por agências. Os carrinhos circulam por praticamente todos os espaços da feira, ruas, becos, por dentro e por fora, dividindo os estreitos caminhos com motocicletas e bicicletas, além de, obviamente, com os transeuntes.

Pertinente considerar a existência de pelo menos dois espaços de concentração dos carrinhos - quando não em uso. Um deles, uma borracharia; o outro, que loca (aluga) carrinhos para os carregadores que não os possuem, este último localizado num dos corredores que conduzem ao fundo da feira. Os trabalhadores que atuam nesta atividade fazem parte de uma 
categoria mais ampla, a de trabalhadores "circulantes", que engloba vendedores de lanche, café, cigarros, dentre outros, além de animadores, divulgadores/ propagandistas e funcionários de empresas de aposta.

Busquei também adentrar o universo das trocas simbólicas e materiais (como quem pega carona num desses carrinhos), a partir das transações e, de modo ampliado, das interações nos setores da feira voltados para a comercialização de artigos religiosos e produtos naturais de cura (ervas, cascas, folhas). Nas primeiras observações, eram dois os espaços com maior concentração de vendedores deste tipo de produto: o galpão água de meninos, na parte provisória, e a rua do muro do exército, na parte mais antiga. Aqui parece ocorrer a incidência de um público mais específico, que busca vendedores e fornecedores em geral já conhecidos. Os diálogos se dão de um modo mais reservado, porém é notória a solidariedade entre os participantes, por exemplo: quando um vendedor não tem disponível o produto procurado, rapidamente um colega é acionado ou o cliente é encaminhado, recebe orientações sobre onde pode conseguir aquele produto. Há certa discrição por parte dos participantes, em geral, motivo pelo qual captar áudio nesses lugares difere de fazê-lo noutros. Isso especialmente no turno matutino, pela tarde não se confirma. O fluxo de pessoas e transações não é tão intenso quanto em outros setores, trata-se de um comércio mais reservado (essa notação foi feita no galpão Água de Meninos; na rua das folhas e na nova estrutura não se confirma). Assim, em termos de compreensão de uma "identidade sonora" da feira, essas partes contribuem, de modo geral, bastante com silêncios e com diálogos mais diretos e discretos. Por outro lado, não é surpresa deparar-se com reencontros e cumprimentos mais calorosos, que compõem também a configuração (ou paisagem) daqueles contextos. 


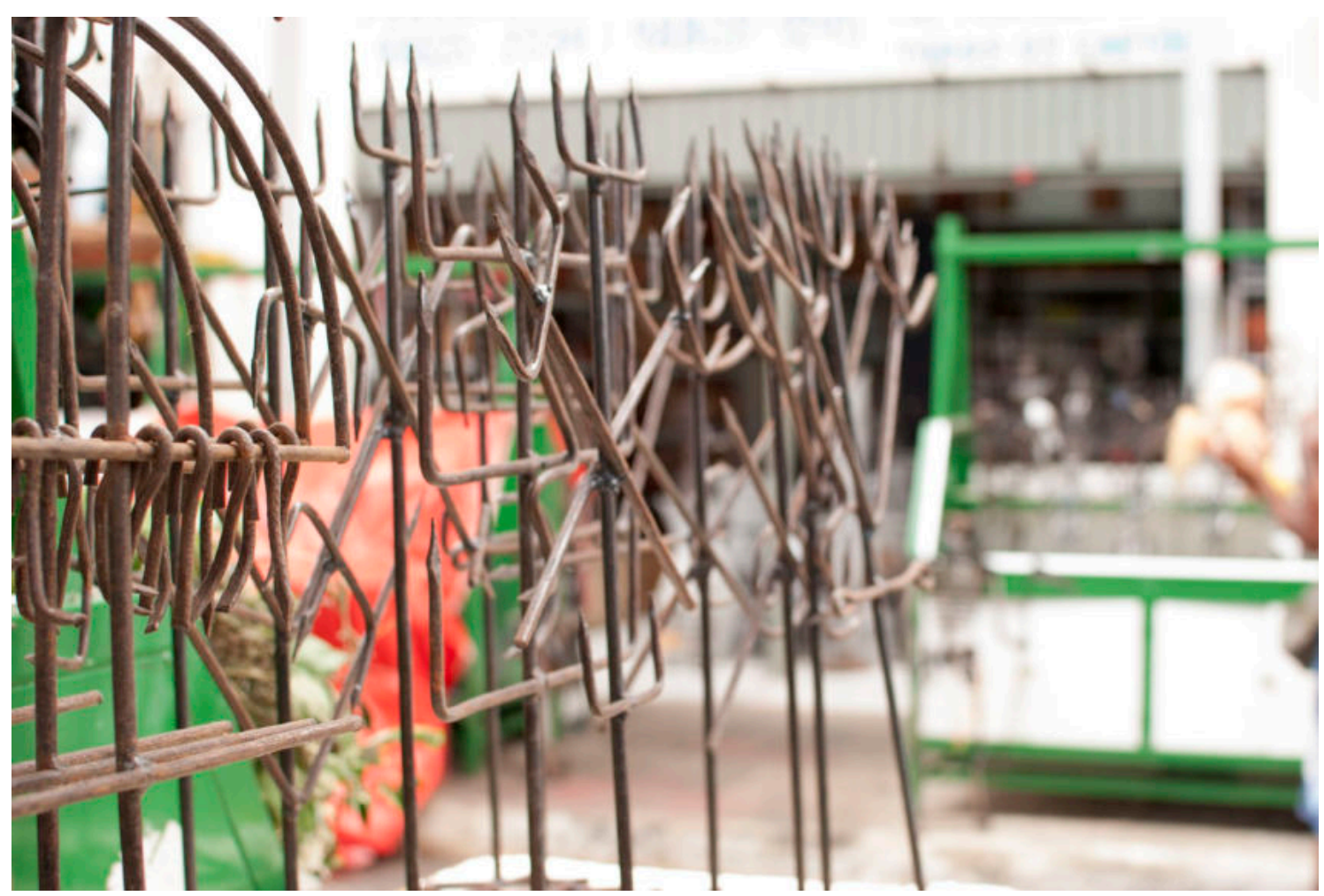

Considero razoável não adentrar, se for de modo superficial, certas questões que parecem girar na esfera de gênero e/ou sexualidade. Entretanto serão feitas referências a expressões com conotação sexual, ao duplo sentido percebido em algumas conversas, certa malícia notada na fala de alguns feirantes, algo que certamente relaciona-se à solidariedade, à interdependência, já que "quebra o gelo", aproxima, induz risos e olhares, visa despertar atenção. Às vezes, emerge como tática de promoção de vendas: "para dor de coluna, cenoura é o melhor remédio"; outras vezes, como provocação ou chacota: "bota um microfone maior na boca dele, que esse tá pequeno", nesse caso, ao que uma senhora responde: "meu Deus do céu", revelando espanto, talvez reprovação, enquanto sugere uma comicidade no comentário. 


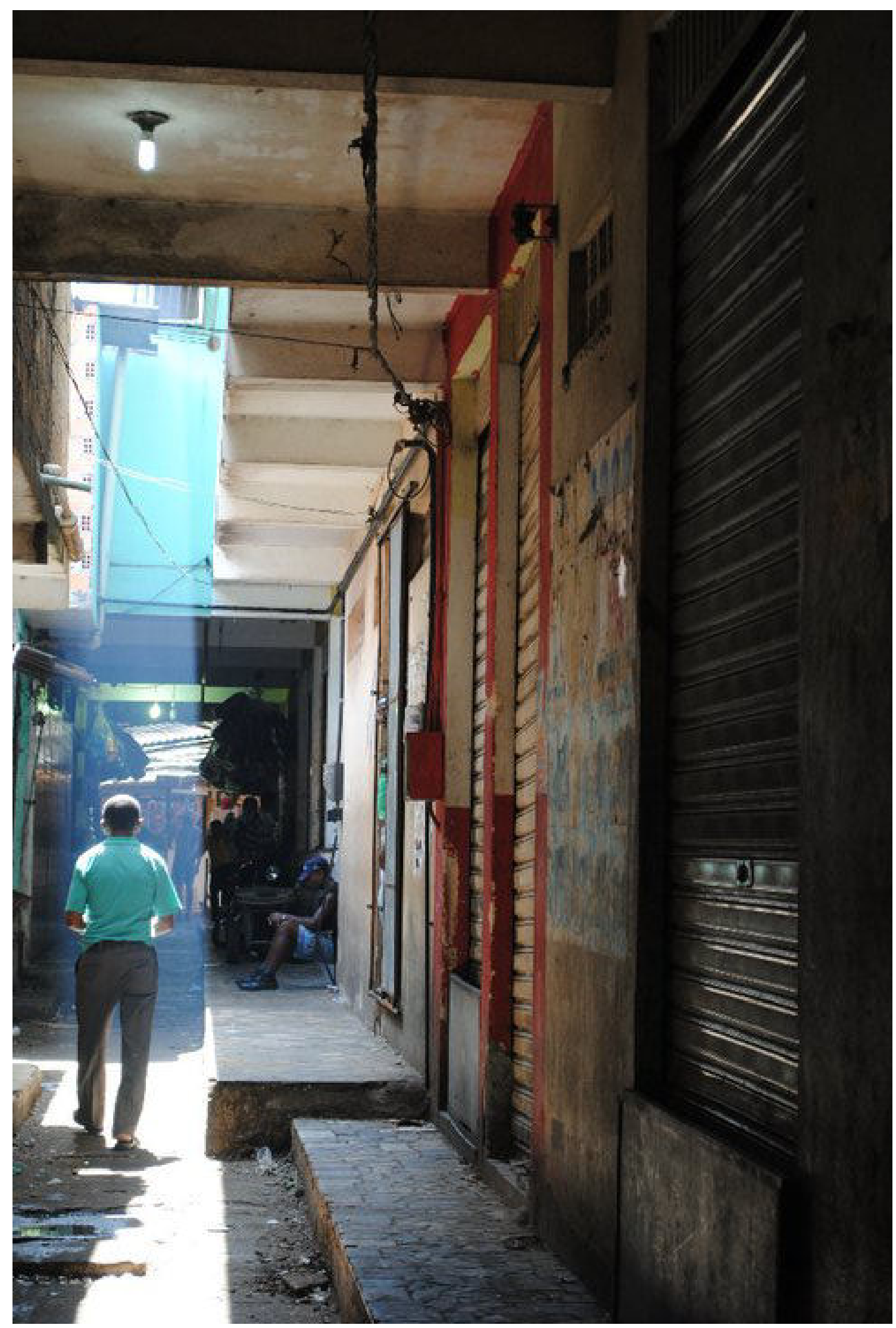




\section{CONSIDERAÇÕES FINAIS}

Após algumas considerações de ordem metodológica, foi esboçada uma descrição do espaço, buscando reconstituir cenas presenciadas ao longo do tempo transcorrido em trabalho de campo, a que se seguiram algumas reflexões sobre a relação pesquisador - gravador - feirantes/ frequentadores, essa mediação por um instrumento de pesquisa adicional na trama, o gravador. Seguiu-se, no plano teórico, o reconhecimento da importância da diversidade de pontos de vista sobre o conceito de paisagem sonora, apontando-se para a compreensão do desenvolvimento, ou expansão, de um conjunto de epistemologias que se opõe ao antropocentrismo e segundo o qual ambiente é meio de conhecimento.

Para além disso, ao longo do texto foram feitos alguns apontamentos, para fins de atualizações acerca da configuração espacial da feira, em acordo com evidências etnográficas e constatações alcançadas durante o trabalho monográfico, finalizado no início de 2017. Quanto aos setores de artigos religiosos, principal vetor a partir do segundo recorte temático dado ao referido trabalho, o que se apresenta enquanto tarefa necessária é buscar, numa relação mais próxima com esses objetos, segui-los ou acompanhá-los em seus percursos, o processo de produção, o escoamento ou circulação e o destino que tomam, aonde eles vão, se e como irão agir, de que modo poderão influenciar ações. Isto, tal qual questões referentes ao aumento de possibilidades a partir do uso de fotografias nas pesquisas antropológicas em contextos urbanos, especialmente na feira em foco, são assunto para uma próxima oportunidade.

Este artigo tentou dar conta das contribuições possíveis com o uso do gravador de áudio, captação e análise de sonoridades sociais, bem como de registros fotográficos, em contexto urbano, numa feira popular de Salvador, Bahia. 


\section{REFERÊNCIAS BIBLIOGRÁFICAS}

CLIFFORD, James. Sobre a autoridade etnográfica. In: A experiência etnográfica. Antropologia e literatura no século XX. Rio de Janeiro: Editora UFRJ. 2011.

DÓREA, Luiz Eduardo. Histórias de Salvador nos nomes das ruas. Col. Bahia de Todos os Santos. Salvador: Edufba. 2006.

Os nomes das ruas contam histórias. Câmara Municipal de Salvador. Cidadania pra valer; “Nossa história é a história da cidade”. Salvador: Edufba. 1999.

FORTUNA, Carlos. Imagens sonoras: sonoridades e ambientes sociais urbanos. Revista Crítica de Ciências Sociais, Lisboa, n. 51, jun. 1998.

GELL, Alfred. Definição do problema: a necessidade de uma antropologia da arte. In: Art and agency. Oxford, Clarendon Press, 1998.

GEERTZ, Cliford. Uma descrição densa: por uma teoria interpretativa da cultura. A interpretação das culturas. Rio de Janeiro: Guanabara, 1989.

INGOLD, Trazendo as coisas de volta à vida: emaranhados criativos num mundo de materiais. In: Horizontes Antropológicos, Porto Alegre, jan./jun. 2012, ano 18, n. 37, p. 25-44.

Estar Vivo: ensaios sobre movimento, conhecimento e descrição. Tradução de Fábio Creder. Petrópolis, RJ: Vozes, 2015. - Col. Antropologia.

LATOUR, Bruno. Jamais Fomos Modernos: ensaio de sociologia simétrica. Tradução de Carlos Irineu da Costa. Rio de Janeiro: 34, 1994 [1991].

A esperança de pandora: ensaios sobre a realidade dos estudos científicos. Tradução de Gilson César Cardoso de Souza. Bauru, SP: Edusc, 2001.

Reagragando o social: uma introdução à teoria do ator-rede. Tradução de Gilson César Cardoso de Souza. Salvador: Edufba, 2012.

MARCONI, Marina de Andrade; PRESOTTO, Zelia Maria Neves. Antropologia: uma introdução. São Paulo: Atlas, 2009. 
MORENO, Ángela Ramírez; BASSI, Francesca. Religião e cura numa igreja pentecostal em Itaparica-Bahia. In: TAVARES, Fátima; GIUMBELLI, Emerson (orgs.). Religiões e temas de pesquisa contemporâneos: diálogos antropológicos.

MELLO, Marcelo M. Murtis em movimento (mimeografado).

NOVAES, Sylvia Caiuby. Entre arte e ciência: usos da fotografia pela antropologia. In: Entre ciência e arte: a fotografia na antropologia. Sylvia Caiuby Novaes (org.). São Paulo: Edusp, 2015.

OLIVEIRA, J.R. de; Oliveira, M.F.S. de. O mercado das folhas: produção e circulação de plantas rituais do candomblé de Salvador, Bahia (avance de investigação em curso), UESB.

OLIVEIRA, Roberto Cardoso de. O trabalho do antropólogo: olhar, ouvir e escrever". In:

O trabalho do antropólogo. 2 ed. Editora Unesp, 2006.

SAMPAIO, Consuelo Novais. 50 anos de urbanização: Salvador no século XIX. São Paulo: Odebrecht, 2005.

SILVA e SÁ, Guilherme José da. Anuário Antropológico/2009 - 1, 2010: 281-284.

PINTO, Tiago de Oliveira. Som e música: questões de uma antropologia sonora. In: Rev. de Antropologia, vol. 44, n. 1, p. 221-286. São Paulo: 2001.

RABELO, Míriam C.M. Estudar a religião a partir do corpo: algumas questões teóricometodológicas. Cadernos CRH, vol. 24, n. 61, p. 15-18. Salvador, jan./ abr., 2011.

ROCHA, Ana L.C. da. Tecnologias audiovisuais na construção de narrativas etnográficas. Um percurso de investigação. In: revista iluminuras, n.11. Porto Alegre: Banco de imagens e efeitos visuais, 2004.

STHRATERN, Marilyn. O efeito etnográfico. In: O efeito etnográfico e outros ensaios. São Paulo: Cosac Naify, 2014.

TARDE, Gabriel. Monadologia e Sociologia e Outros Ensaios. São Paulo: Cosac \& Naify, 2007.

VEDANA, Viviane. Fazer a feira e ser feirante: a construção cotidiana do trabalho em mercados de rua no contexto urbano. Horizontes Antropológicos, Porto Alegre, Jun 2013, vol. 19, n. 39, p. $41-68$.

Diálogos entre imagem visual e imagem sonora: a experiência de escritura do sonoro nos documentários etnográficos. In: Ciberlegenda, n.24, Rio de Janeiro, RJ, 2011. 